\title{
PENGARUH PARTISIPASI PENYUSUNAN ANGGARAN TERHADAP KINERJA MANAJERIAL PADA BPR DI WILAYAH OTORITAS JASA KEUANGAN PURWOKERTO
}

\author{
Sri Indrawati ${ }^{1}$ \\ ${ }^{1}$ Program Pascasarjana Magister Manajemen, Fakultas Ekonomi dan Bisnis, Universitas Jenderal \\ Soedirman, Indonesia. \\ *Email corresponding: indrawati172@gmail.com
}

\begin{abstract}
Abstrak
Industri perbankan telah mengalami perkembangan dimana persaingan semakin kompetitif, sehingga dalam mencapai tujuan organisasi diperlukan Anggaran yang berisi rencana finansial dan nonfinasial yang berfungsi sebagai acuan dalam menjalankan organisasi untuk mencapai tujuan organisasi. Bank Perkreditan Rakyat di bawah pengawasan Otoritas Jasa Keuangan wajib menyusun Rencana Bisnis, menurut Peraturan Otoritas Jasa Keuangan No: 37/POJK.03/2016 tentang Rencana Bisnis Bank Perkreditan Rakyat dan Bank Pembiayaan Rakyat Syariah, dimana penyusunan Rencana Bisnis Bank berfungsi untuk mengarahkan kegiatan operasional BPR sesuai dengan visi dan misinya, menetapkan sasaran strategis dan nilai perusahaan yang dijabarkan. Partisipasi penyusunan Rencana Bisnis Bank sejauh mana bawahan berpartisipasi dalam penyusunan anggaran. Penelitian ini bertujuan menguji pengaruh partisipasi anggaran terhadap kinerja manajerial pada Bank Perkreditan Rakyat di wilayah Otoritas Jasa Keuangan Purwokerto. Populasi dalam penelitian ini adalah 22 Bank Perkreditan Rakyat. Pengumpulan data dilakukan dengan cara membagikan kuesioner melalui google form ditujukan kepada Direksi BPR, ada 35 direksi yang ikut berpartisipasi dalam penelitian ini. Metode analisis data yang digunakan dalam penelitian ini adalah regresi sederhana. Hasil penelitian ini menunjukkan bahwa partisipasi penyusunan anggaran berpengaruh signifikan terhadap kinerja manajerial. Kesimpulannya partisipasi penyusunan Rencana Bisnis Bank sangat mendukung terhadap kinerja manajerial.
\end{abstract}

Kata Kunci: Partisipasi Penyusunan Anggaran, Kinerja Manajerial, Bank Perkreditan Rakyat

\begin{abstract}
The banking industry has experienced a development in which competition is increasingly competitive, so in achieving organizational goals a Budget is needed that contains financial and non-financial plans that serve as a reference in running the organization to achieve organizational goals. Rural Credit Banks under the supervision of the Financial Services Authority are required to draw up a Business Plan, according to the Financial Services Authority Regulation No: 37 / POJK.03 / 2016 concerning Business Plans for Rural Credit Banks and Islamic People's Financing Banks, where the preparation of the Bank Business Plan functions to direct operational activities BPR in accordance with its vision and mission, set strategic goals and company values outlined. Participation in preparing the Bank Business Plan to what extent subordinates participate in preparing the budget. This study aims to examine the effect of budgetary participation on managerial performance in the Rural Credit Bank in the area of the Purwokerto Financial Services Authority. The population in this study was 22 People's Credit Banks. Data collection was carried out by distributing questionnaires through Google form addressed to the BPR Directors, there were 35 directors who participated in this study. The data analysis method used in this study is simple regression. The results of this study indicate that budgetary participation significantly influences managerial performance. In conclusion, participation in the preparation of the Bank's Business Plan is very supportive of managerial performance.
\end{abstract}

Keywords: Budgeting Participation, Managerial Performance, Rural Credit Banks 


\section{PENDAHULUAN}

Dalam menjalankan organisasi pada era perdagangan bebas sekarang ini, perusahaanperusahaan memasuki lingkungan bisnis yang berbeda dengan lingkungan bisnis sebelumnya, tidak hanya pesaing domestik saja, melainkan pesaing-pesaing mancanegara yang menawarkan produk barang dan jasa dengan pengetahuan tingkat dunia, manajemen perusahaan harus mampu mempertahankan kelangsungan hidup perusahaannya di lingkungan bisnis global. Perubahan yang terjadi salah satunya adalah kompetesi yang tajam dimana Bank Umum dan lembaga keuangan mikro lainnya menyalurkan kredit dengan pangsa pasar yang sama dengan Bank Perkreditan Rakyat, sehingga Bank Prekreditan Rakyat berusaha agar dapat bertahan dan terus maju serta berkembang, sehingga memerlukan perangkat khusus baik pada faktor stratejik maupun aspek operasional dalam menjalankan suatu organisasi perusahaan yaitu dengan membuat anggaran atau Rencana Bisnis. Oleh karena itu Bank Perkreditan Rakyat di bawah pengawasan Kantor Otoritas Jasa Keuangan diwajibkan menyusun anggaran tahunan yang di sebut Rencana Bisnis Bank. Sesuai Peraturan Otoritas Jasa Keuangan No:37/POJK.03/2016 tentang Rencana Bisnis Bank Perkreditan Rakyat dan Bank Pembiayaan Rakyat Syariah, dimana penyusunan Rencana Bisnis Bank berfungsi untuk mengarahkan kegiatan operasional Bank Perkreditan Rakyat sesuai dengan visi dan misinya, menetapkan sasaran strategis dan nilai perusahaan yang dijabarkan merupakan acuan bagi pengawas Bank Perkreditan Rakyat dalam menyusun rencana pengawasan yang opimal dan efektif.

Rencana Bisnis Bank Perkreditan Rakyat yang berisi: ringkasan ekskutif, strategi bisnis dan kebijakan, proyeksi laporan keuangan, target rasio-rasio dan pos-pos keuangan, rencana penghimpunan dana, rencana penyaluran dana, rencana permodalan, rencana pengembangan organisasi, tehnologi informasi dan Sumber Daya Manusia (SDM), rencana pelaksanaan kegiatan usaha baru atau rencana penerbitan produk dan pelaksanaan aktivitas baru, rencana pengembangan dan/atau perubahan jaringan kantor, dan informasi lainnya. Rencana Bisnis disusun oleh Bank Perkreditan Rakyat meliputi rencana jangka pendek, jangka menengah, dan/atau rencana strategis jangka panjang. Dalam penyusunan Rencana Bisnis Bank Perkreditan Rakyat dengan memperhatikan faktor ekstern dan intern yang dapat mempengaruhi kelangsungan usaha Bank Perkreditan Rakyat, prinsip kehati-hatian dan asas perbankan yang sehat. Rencana Bisnis Bank ini berfungsi sebagai acuan bagi manajemen dalam menjalankan organisasi dan telah di susun untuk beberapa tahun ke depan.

Rencana Bisnis Bank adalah suatu anggaran yang digunakan sebagai pedoman dalam melaksanakan operasional bank, yang mana anggaran selaras dengan visi dan misi dari Bank Perkreditan Rakyat atau Bank Pembiayaan Rakyat Syariah. Suatu anggaran akan tercapai apabila dipahami dan didukung oleh karyawan, supaya suatu anggaran didukung oleh karyawan salah satu caranya dengan partisipasi karyawan dalam penyusunan anggaran.

Anggaran adalah laporan-laporan formal sumber daya-sumber daya keuangan yang disisihkan untuk melaksanakan kegiatan-kegiatan tertentu selama periode waktu yang ditetapkan. Anggaran menunjukkan pengeluaran, penerimaan atau laba yang direncanakan di waktu yang akan datang. Anggaran mencerminkan sasaran, rencana dan program-program organisasi yang dinyatakan dalam bentuk bilangan. Angka-angka perencanaan ini menjadi standar di mana pelaksanaan di waktu yang akan datang dapat diukur (Handoko, 1997).

Dalam Safitri (2006), anggaran merupakan implementasi dari rencana yang telah ditetapkan perusahaan. Anggaran juga merupakan proses pengendalian manajemen yang melibatkan komunikasi dan interaksi formal di kalangan para manajer dan karyawan dan merupakan pengendalian manajemen atas operasional perusahaan pada tahun berjalan. 
Program atau rencana strategik yang telah disetujui pada tahap sebelumnya, merupakan titik awal dalam mempersiapkan anggaran.

Anggaran menunjukkan jabaran dari program dengan menggunakan informasi terkini. Menurut Anthony dan Govindarajan (2002), anggaran merupakan alat yang utama dalam perencanaan jangka pendek yang efektif dan pengendalian dalam organisasi. Sebuah anggaran operasi biasanya dalam satu tahun dan menyatakan rencana pendapatan biaya untuk tahun yang bersangkutan.

Perencanaan dan penyusunan anggaran merupakan suatu aktivitas penting dan rutin yang selalu dilakukan perusahaan dalam setiap awal tahun anggaran atau sebelum melaksanakan suatu proyek . Aktivitas tersebut bukan hanya merupakan suatu tugas teknis yang menyangkut aspek-aspek keuangan, angka-angka akuntansi dan estimasi terhadap pengeluaran-penerimaan dan laba rugi (profit-loss) perusahaan untuk satu periode tahun anggaran ke depan atau dalam satu proyek yang diselesaikan seperti yang dipahami oleh kebanyakan perusahaan selama ini, akan tetapi aktivitas tersebut juga menyangkut pertimbangan terhadap aspek-aspek keperilakukan manusia yang merencanakan, menyusun, melaksanakan, mengendalikan dan mengevaluasi kinerja anggaran tersebut (Lako, 2004).

Suatu anggaran yang disusun menunjukan proyeksi peningkatan kinerja perusahaan dan strategi-strategi yang akan dilakukan, dengan pencapaian anggaran maka kinerja manajerial akan meningkat. Kinerja adalah gambaran mengenai tingkat pencapaian pelaksanaan suatu kegiatan/program/kebijakan dalam mewujudkan sasaran, tujuan, misi, dan visi organisasi yang tertuang dalam rencana strategis suatu organisasi (Mardiasmo, 2009). Sedangkan Mangkunegara (2005) menyatakan bahwa kinerja (prestasi kerja) adalah hasil kerja secara kualitas dan kuantitas yang dicapai oleh seorang pegawai dalam melaksanakan tugasnya sesuai dengan tanggungjawab yang diberikan kepadanya.

Partisipasi dalam penyusunan anggaran adalah proses dimana karyawan diberi kesempatan untuk terlibat dan memiliki pengaruh dalam proses penyusunan anggaran (Yuen, 2007). Dalam kegiatan partisipasi, para partisipan harus ikut berkontribusi (Lowin, 1968). Pentingnya partisipasi dalam penyusunan anggaran dapat memberikan dampak 2 arah. Pertama, proses partisipasi akan meminimalkan informasi asimetris dalam perusahaan sehingga memungkinkan para manajer mendapatkan informasi tentang masalah yang dihadapi oleh karyawannya. Kedua, proses partisipasi dapat meningkatkan komitmen karyawan untuk melaksanaan rencana anggaran sehingga target anggaran dapat terpenuhi (Welsch, Hilton, Gordon, 2000). Menurut Simamora (2012) bahwa para manajer akan lebih termotivasi mencapai tujuan anggaran apabila mereka memahami anggaran dan terlibat dalam penyusunan anggaran tersebut. Selain itu partisipasi karyawan dalam penyusunan anggaran juga akan meningkatkan kepercayaan karyawan pada perusahaan, membuat karyawan bisa menerima hasil dari penyusunan target (budget goal). Melalui partisipasi dalam penganggaran, bawahan mengembangkan perasaan mental dan emosional yang menjadikan mereka merasa memiliki tanggungjawab dalam pencapaian tujuan anggaran (Owen, 1987).

Berdasarkan riset gap tersebut diatas, maka penelitian akan melakukan penelitian partisipasi anggaran terhadap kinerja manajerial pada Bank Perkreditan Rakyat di Wilayah Otoritas Jasa Keuangan Purwokerto. 


\section{TINJAUAN PUSTAKA DAN PERUMUSAN HIPOTESIS}

\section{Partisipasi Anggaran}

Budgeting participation adalah proses dimana karyawan diberi kesempatan untuk terlibat dan memiliki pengaruh dalam proses penyusunan budget (Yuen, 2007). Dimana tingkat keterlibatan dan pengaruh karyawan dalam proses penyusunan budget merupakan faktor utama yang membedakan budget partisipatif dan non partisipatif (Brownell dan MCInnes, 1986). Dalam kegiatan partisipasi, para partisipan harus ikut berkontribusi Lowin (1968). Selain itu, terjadinya bugdeting participation dalam suatu perusahaan merupakan proses involvement, influence, dan contribution dalam penyusunan budget. (Kren, 1992; Magner, Welker dan Campbell, 1996 dan Chong, Eggleton dan Leong, 2005) dimana keterlibatan (Involvement) dalam hal ini budgeting participation dilihat dari seberapa bagian atau porsi keterlibatan karyawan dalam menyusun budget, pengaruh (Influence) dengan melihat seberapa besar pengaruh yang dirasakan karyawan terhadap final budget (anggaran final), dan kontribusi (Contribution) adalah seberapa penting kontribusi yang diberikan karyawan dalam penyusunan budget.

Menurut Hoque (2005) yang menyatakan budgeting participation dapat menghasilkan manfaat seperti mendorong kreativitas di semua tingkatan karyawan, meningkatkan rasa tanggung jawab, dan juga meningkatkan komitmen karyawan untuk budget goal. Dan Argyris (1952), berpendapat bahwa ikut berpartisipasi dalam proses penyusunan budget berfungsi mendorong karyawan untuk menerima dan berkomitmen dengan budget goal mereka.

Menurut Brownell (1982b) dalam Sumarno (2005), partisipasi anggaran adalah tingkat keterlibatan dan pengaruh individu dalam penyusunan anggaran, sementara Chong (2002) menyatakan sebagai proses dimana bawahan/pelaksana anggaran diberikan kesempatan untuk terlibat dalam dan mempunyai pengaruh dalam proses penyusunan anggaran. Kesempatan berpartisipasi yang diberikan diyakini meningkatkan pengendalian dan rasa keterlibatan dikalangan bawahan/pelaksana anggaran (Ompusungu dan Banowo, 2007). Oleh Kenis (1979), juga Siegel dan Marconi (1989) didefinisikan partisipasi penyusunan anggaran adalah keterlibatan para manajer dalam menyusun anggaran tersebut pada pusat pertanggung jawaban manajer yang bersangkutan.

Cherrington dan Cherrington (1973) anggaran adalah alat utama bisnis untuk menggambarkan suatu rencana, untuk mengkoordinasikan dan mengimplementasikan rencana tersebut, mengevaluasi usaha yang dilakukan terhadap pencapaian hasil, dan untuk mengendalikan aktivitas didalam organisasi. Menurut Hansen dan Mowen, (2001) anggaran adalah suatu pernyataan formal yang dibuat oleh manajemen tentang rencana-rencana yang akan dilakukan pada masa yang akan datang dalam suatu periode tertentu, dimana rencana tersebut mengidentifikasikan tujuan dan tindakan yang diperlukan untuk mencapainya dan digunakan sebagai pedoman dalam pelaksanaan kegiatan selama periode tersebut. Menurut Mardiasmo, (2009) anggaran merupakan pernyataan estimasi kinerja yang akan di capai selama periode waktu tertentu yang dinyatakan dalam ukuran finansial, sedangkan pengganggaran adalah proses metode untuk mempersiapakan suatu anggaran. Sedangkan menurut Simamora (2012) anggaran adalah sebuah rencana kuantitatif kegiatan usaha sebuah organisasi, anggaran mengidentifikasikan sumber daya dan komitmen yang dibutuhkan untuk memenuhi tujuan organisasi selama periode yang dianggarkan. 
Partisipasi anggaran yaitu tingkat keterlibatan dan pengaruh para individu dalam proses penyusunan anggaran (Brownell, 1982). Milani (1975) menyatakan bahwa partisipasi dalam penyusunan anggaran berkaitan dengan seberapa jauh keterlibatan manajer didalam menentukan atau menyusun anggaran yang ada dalam departemen atau bagiannya, baik secara periodik maupun tahunan. Menurut Argyris (1952) proses penyusunan anggaran merupakan kegiatan yang penting dan sekaligus kompleks, karena mempunyai dampak fungsional atau disfungsional terhadap sikap dan prilaku anggota organisasi. Anggaran yang terlalu menekan cenderung akan menimbulkan sikap agresi pekerja (bawahan) terhadap manajemen (atasan) dan menyebabkan ketegangan yang memungkikan inefisiensi. Hal tersebut dapat terjadi karena kemungkinan anggaran yang disusun terlalu kaku atau target yang ditetapkan dalam anggaran terlalu sulit untuk dicapai. Aspek negatif dari anggaran dapat menimbulkan konflik dan ketidaknyamanan diantara anggota organisasi. Untuk mengatasi kemungkinan dampak disfungsional, disarankan perlunya bawahan diberi kesempatan untuk berpartisipasi dalam proses penyusunan anggaran. Tujuan yang diinginkan/rencana perusahaan akan lebih dapat diterima, jika anggota organisasi dapat bersama-sama dalam suatu kelompok mendiskusikan pendapat mereka mengenai tujuan perusahaan, dan terlibat dalam menentukan langkah-langkah untuk mencapai tujuan tersebut. Anggaran yang telah disusun mempunyai dua fungsi, pertama anggaran berfungsi sebagai perencanaan, yaitu bahwa anggaran berisi tentang ringkasan rencana-rencana keuangan organisasi di masa yang akan datang. Kedua, anggaran berfungsi sebagai kriteria kinerja, yaitu anggaran digunakan sebagai sistem pengendalian untuk mengukur kinerja manajerial. Menurut Hansen dan Mowen (2009) penggangaran mempunyai manfaat bagi organisasi, yaitu: memaksa para manajer untuk melakukan perencanaan, menyediakan informasi yang dapat digunakan dalam memperbaiki pengambilan keputusan, menyediakan standard evaluasi kinerja, memperbaiki komunikasi dan koordinasi.

\section{Kinerja Manajerial}

Kinerja adalah gambaran mengenai tingkat pencapaian pelaksanaan suatu kegiatan/program/kebijakan dalam mewujudkan sasaran, tujuan, misi, dan visi organisasi yang tertuang dalam rencana strategis suatu organisasi (Mardiasmo,2009). Sedangkan Mangkunegara (2005) menyatakan bahwa kinerja (prestasi kerja) adalah hasil kerja secara kualitas dan kuantitas yang dicapai oleh seorang pegawai dalam melaksanakan tugasnya sesuai dengan tanggungjawab yang diberikan kepadanya. Menurut Mahmudi (2010) dalam menciptakan sistem kinerja yang efektif, peran manajer sangat menentukan, karena manajer bertanggungjawab untuk: menciptakan kondisi yang dapat memotivasi karyawan, melakukan observasi kinerja, memperbaharui dan menyesuaikan tujuan, standard kinerja, dan kompetensi kerja apabila terjadi perubahan kondisi, memberikan umpan balik atas kinerja bawahan dan pengarahan, memberikan up grading dan pengembangan kemampuan pegawai, memberikan penguatan perilaku untuk mencapai tujuan organisasi.

Kinerja manajerial yaitu kinerja para individu dalam kegiatan-kegiatan manajerial, perencanaan, investigasi, koordinasi, supervisi, staffing, negosiasi dan refresentasi, menurut Mahoney et al (1963). Manajemen mempunyai tugas penting seperti perencanaan, pengkoordinasian tugas bawahan, pengendalian dan pengambilan keputusan. Manajemen harus memberi tugas kepada para bawahan, menjabarkan apa yang dikehendaki oleh manajemen dan merangsang karyawan agar bersama-sama manajemen mencapai tujuan perusahaan. 
Menurut Wibowo (2010), Kinerja Manajerial memberikan manfaat bagi perusahaan secara keseluruhan, manajer, dan juga setiap individu di dalam organisasi. Adapun manfaat bagi perusahaan adalah: sebagai acuan untuk penyesuaian tujuan organisasi dengan tujuan tim dan individu dalam memperbaiki kinerja pegawai, untuk meningkatkan komitmen kerja pegawai, untuk memperbaiki proses training dan pengembangan, untuk meningkatkan keterampilan pegawai, sebagai upaya perbaikan dan pengembangan secara berkesinambungan, sebagai upaya basis perencanaan karir karyawan, sebagai upaya mempertahankan karyawan berkualitas, untuk mendukung program perubahan budaya kerja, untuk mendukung inisiatif kualitas total dan pelayanan konsumen. Sedangkan manfaat bagi Manajer adalah: untuk membantu upaya klasifikasi kinerja dan harapan perilaku, untuk memperbaiki kinerja tim dan individu pekerja, untuk menawarkan peluang memanfaatkan waktu secara berkualitas, sebagai upaya memberikan penghargaan non-finansial bagi karyawan, untuk membantu karyawan yang kinerjanya kurang baik, untuk pengembangan diri karyawan, sebagai pendukung kepemimpinan, untuk memotivasi dan pengembangan kerjasama tim, sebagai upaya membuat kerangka kerja untuk meninjau kembali tingkat kompetensi dan kinerja. Disisi lain ada manfaat bagi seluruh pegawai yaitu: sebagai informasi peran dan tujuan karyawan, untuk mendorong dan mendukung kinerja karyawan, untuk membantu mengembangkan kinerja dan kemampuan karyawan, sebagai peluang untuk memanfaatkan waktu yang berkualitas, sebagai dasar objektivitas dan kejujuran dalam mengukur kinerja, untuk membantu agar pegawai fokus pada tujuan, rencana perbaikan, dan cara bekerja.

\section{Bank Perkreditan Rakyat}

Menurut UU perbankan no 10 tahun 1998, BPR adalah bank yang melakukan aktivitas usaha baik dengan konvensional atau berdasarkan dengan Prinsip Syariah dimana dalam kegiatannya tidak memberikan pelayanan/jasa dalam lalu lintas pembayaran. Berdasarkan pengertian tersebut dapat diketahui bahwa fungsi BPR adalah sebagai penghimpun dana dari masyarakat yang kelebihan dana (surplus) dan menyalurkan kembali kepada masyarakat yang kekurangan dana (deficit). Sehingga karena hal ini bank juga disebut sebagai lembaga kepercayaan (agent of trust).

Menurut Peraturan Otoritas Jasa Keuangan Nomor 20/POJK.03/2014 Tentang Bank Perkreditan Rakyat, Bank Perkreditan Rakyat adalah Bank yang melaksanakan kegiatan usaha secara konvensional atau berdasarkan prinsip syariah yang dalam kegiatannya tidak memberikan jasa lalu lintas pembayaran sebagaimana dimaksud dalam undang-undang perbankan.

Di Indonesia secara umum keberadaan BPR dikatakan telah mampu membantu perkembangan usaha masyarakat, apalagi untuk usaha mikro, kecil dan menengah (UMKM) dengan lokasi yang juga dekat dengan tempat tinggal masyarakat yang membutuhkan (Chou \& Buchdadi, 2016). BPR sebagai salah satu dari lembaga keuangan perbankan, peran dari BPR sangat menentukan keberhasilan dari ekonomi masyarakat yang ada dilingkungannya. Ruang lingkup kegiatan BPR dapat dikatakan terbatas bila dibanding dengan Bank Umum. Hal ini sesuai dengan ketentuan yang tertera pada Undang-Undang Perbankan (Undang-undang RI No. 10, 1998)

Pelayanan BPR sebagian besar diberikan kepada masyarakat yang bermodal kecil, yang sebagian besar berada dalam sektor informal. Oleh karena itu perbaikan kinerja baik manajemen, administrasi harus ditingkatkan kualitasnya. Disamping menyangkut perkembangan BPR itu 
sendiri juga menyangkut perkembangan sektor riil yang tumbuh dari sektor informal yang merupakan bagian terbesar dari perekonomian masyarakat. (Septianto, 2010).

\section{Penelitian Terdahulu}

Dari beberapa penelitian yang telah dilakukan sebelumnya yaitu Penelitian Brownell (1983), Brownell dan Mclnnes (1986), Murwaningsari (2008), Wahyuningsih dan Pramuka (2012), Febriyanti dan Riharjo (2013), Kamilah.et.al. (2013), Deliana (2015) dan Wiratno, et.al. (2016) menemukan bahwa partisipasi anggaran mempengaruhi kinerja manajerial. Sedangkan penelitian Syahputra (2014) dan Rahman (2014) tidak menemukan adanya hubungan antara partisipasi anggaran dengan kinerja manajerial.

\section{Kerangka Pemikiran dan Hipotesis}

Beberapa penelitian terdahulu yang meneliti hubungan antara partisipasi anggaran dengan kinerja menajerial, menunjukan hasil yang beragam. Penelitian Wiratno et al. (2016), Deliana (2015), Febrianti dan Riharjo (2013), Kamilah et al.(2013), Wahyuningsih dan Pramuka (2012), menunjukan hasil yang positif pada pengaruh partisipasi anggaran pada kinerja. Sedangkan penelitian Rahman (2014), Syahputra (2014) menunjukan hasil yang negatif. Hal ini menunjukan bahwa penelitian tentang partisipasi anggaran dan kinerja manajerial masih relevan untuk dilakukan.

Dalam meningkatkan kinerja manajerial salah satu faktor adalah partisipasi anggaran, dimana dalam anggaran di tetapkan target-target dan tujuan organisasi yang akan dicapai dalam jangka tertentu. Penetapan tujuan dengan secara partisipatif dapat menjadi sumber motivasi karyawan, yang mana karyawan yang berpartisipasi dalam penetapan tujuan maka mereka akan berusaha lebih keras untuk mencapai tujuan tersebut.

Teori penetapan tujuan menyatakan bahwa karyawan membuat komitmen untuk mencapai tujuan mereka (Locke \& Latham, 1990). Teori ini menjelaskan hubungan-hubungan antara niat/intention (tujuan-tujuan) dengan perilaku. Dimana tujuan yang cukup sulit, khusus dan yang pernyataannya jelas dan dapat diterima oleh karyawan, akan menghasilkan hasil kerja yang lebih tinggi daripada tujuan-tujuan yang kabur, tidak khusus, dan yang mudah dicapai. Goal Setting theory menyatakan bahwa ketika tujuan dibuat bersama, masing-masing akan mempunyai rasa tanggung jawab untuk mencapainya, sehingga kinerja akan meningkat (Locke, 1990). Pernyataan ini didukung pendapat Milani (1975), bahwa peran partisipasi anggaran diharapkan dapat meningkatkan kinerja manajerial. Partisipasi manajer dalam proses penyusunan anggaran diharapkan dapat meningkatkan perasaan dihargai, meningkatkan rasa tanggung jawab atas anggaran yang telah disusun dan meningkatkan kinerja manajerial (Deliana,2015), hasil penelitian ini menunjukan bahwa partisipasi anggaran oleh manajer berpengaruh positif terhadap kinerja manajerial. Penelitian Fakile et.al (2016) menyatakan partisipasi bawahan dalam penyusunan anggaran akan mendukung kejelasan tujuan anggaran dan pencapaian tujuan anggaran, dengan tercapainya tujuan anggaran maka akan meningkatkan kinerja managerial. Didukung juga penelitian Ramallo (2016), dengan partisipasi anggaran akan menurunkan asimetris informasi sehingga masing-masing pihak memiliki informasi yang akan mendukung tujuan anggaran. 


\section{Hipotesis Penelitian}

H1 : Partisipasi anggaran berpengaruh positif terhadap kinerja manajerial BPR

\section{METODOLOGI}

\section{Populasi dan Sampel}

Populasi dalam penelitian ini ada 22 Bank Perkreditan Rakyat di wilayah Otoritas Jasa Keuangan Purwokerto, dimana sesuai dengan Peratusran dari otoritas Jasa Keuangan bahwa 1(satu) Bank Perkreditan Rakyat diwajibkan memiliki minimal 2(dua) orang direksi. Pengambilan sampel dilakukan dengan menggunakan metode probability sampling dengan cluster sampling . Sedangkan responden dalam penelitian ini adalah Direksi di wilayah kerja Otoritas Jasa Keuangan Purwokerto dan telah memiliki masa kerja di tempat bekerja saat ini minimal 1 tahun sehingga yang bersangkutan telah memahami mekanisme anggaran yang berlaku di tempat kerja dan sudah mampu mengukur kinerjanya.

\section{Pengumpulan Data}

Penelitian yang digunakan adalah data primer, yaitu data yang dikumpulkan dengan mengirimkan kuesioner menggunakan google form kepada Direktur Utama Bank Perkreditan Rakyat di wilayah Kantor Otoritas Jasa Keuangan Purwokerto, dan selanjutnya direktur utama akan meneruskan kepada direksi yang lain yaitu kepada direksi kepatuhan, direksi operasional.

\section{Definisi Operasionalisasi Variabel dan Pengukurannya}

Partisipasi Anggaran didefinisikan sebagai proses dimana direksi diberi kesempatan untuk terlibat dan memiliki pengaruh pada proses penyusunan anggaran. Instrumen untuk mengukur variabel partisipasi anggaran mengadopsi instrumen yang digunakan dalam penelitian Milani (1975), dengan dimensi keterlibatan dalam penyusunan anggaran dan pengaruh dalam penyusunan anggaran. Dimana indikatornya: keikutsertaan dalam penyusunan anggaran, penjelasan oleh atasan atas alasan revisi anggaran, kontrisbusi dalam penyusunan angaran, frekuensi pemberian saran terkait anggaran, frekuensi permintaan pendapat terkait anggaran. Jawaban responden diukur dengan menggunakan skala Likert 1-5. Skor 1 untuk jawaban TIDAK PERNAH, skor 2 untuk jawaban PERNAH, skor 3 untuk jawaban KADANG, skor 4 untuk jawaban SERING dan skor 5 untuk jawaban SELALU.

Kinerja manajerial yaitu kinerja para individu dalam kegiatan-kegiatan manajerial, perencanaan, investigasi, koordinasi, supervisi, staffing, negosiasi dan refresentasi. Instrumen untuk mengukur variabel kinerja manajerial mengadopsi instrumen yang digunakan dalam penelitian Mahoney, et al.(1963), dengan dimensi: perencanaan, investigasi, pengkoordinasian, evaluasi, perwakilan, staffing, negosiasi, representasi. Dimana indikatornya adalah: penentuan tujuan, kebijakan dan rencana kerja, pengumpulan dan penyiapan informasi dalam bentuk catatan dan laporan, pertukaran informasi dengan organisasi serta bagian lain untuk penyesuaian program, pengukuran dan penilaian hasil pekerjaan, mengemukakan gagasan organisasi kepada pihak lain baik individu maupun organisasi, menempatkan bawahan dan memberi tugas sesuai dengan potensi yang dimiliki, melakukan negosiasi dengan pihak ketiga, mengkomunikasikan semua hal mengenai organisasi. Jawaban responden diukur dengan 
menggunakan skala Likert 1-5. Skor 1 untuk jawaban TIDAK PERNAH, skor 2 untuk jawaban PERNAH, skor 3 untuk jawaban KADANG, skor 4 untuk jawaban SERING dan skor 5 untuk jawaban SELALU.

\section{ANALISIS DATA}

Dalam penelitian ini menggunakan metode analisis regresi linear sederhana. Untuk menguji analisi dalam penelitian ini dilakukan membuat persamaan regresi variabel independen atau bebas $(\mathrm{X})$ terhadap variabel dependen atau terikat $(\mathrm{Y})$.

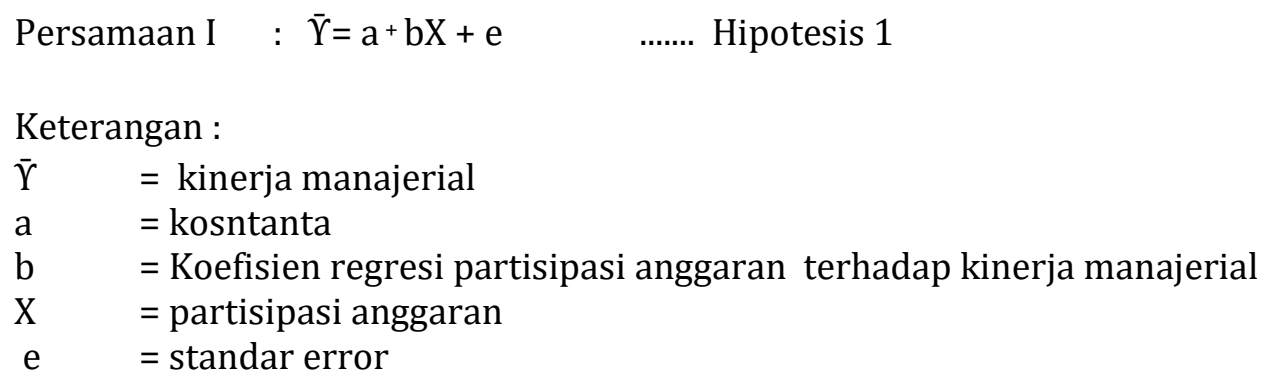

\section{HASIL PENELITIAN DAN PEMBAHASAN}

Penelitian ini menggunakan kuesioner dengan google form untuk pengumpulan data yang dikirimkan kepada direktur utama Bank Perkreditan Rakyat di wilayah Otoritas Jasa Keuangan Purwokerto. Dari 22 Bank Perkreditan Rakyat yang ada di wilayah Kantor Otoritas Jasa Keuangan Purwokerto dengan masing-masing Bank Perkreditan Rakyat di wajibkan memiliki minimal 2 direksi yang berpartispasi sebagai responen sebanyak 35. Kinerja manajerial, dalam penelitian ini untuk menilai kinerja manajerial digunakan 9 pertanyaan. Total skor jawaban responden diperoleh sebesar 1.318 dengan nilai minimal sebesar 26, nilai maksimal sebesar 45, dan ratarata sebesar 37,66, median 37 dan modus 35. Sedangkan Partisipasi anggaran, dalam penelitian ini untuk menilai partisipasi anggaran digunakan 6 pertanyaan. Total skor jawaban responden diperoleh sebesar 915 dengan nilai minimal sebesar 24, nilai maksimal sebesar 30, dan rata-rata skor sebesar 26,14, median 25 dan modus 24.

\section{Uji Kualitas Data}

Hasil pengujian validitas data untuk variabel kinerja manajerial dan partisipasi anggaran yaitu diperoleh nilai $r$ tabel dengan persamaan $\mathrm{N}-2$ yaitu $35-2=33=0,334$. Nilai $r$ hitung dalam uji ini adalah pada kolom Corrected Item Total Correlation. Diketahui nilai $r$ hitung $>0,334$. Artinya seluruh item variabel kinerja manajerial dan partisipasi anggaran dinyatakan valid. Reliabilitas data diuji dengan statistik Cronbach's Alpha (a). Suatu konstruk variabel dikatakan baik jika memiliki nilai Cronbach's Alpha > 0,60. Berdasarkan hasil pengujian, Cronbach's Alpha untuk variabel kinerja manajerial sebesar 0,825>0,60 dan partisipasi anggaran sebesar 0,611 >0,60, 
sehingga dapat disimpulkan bahwa alat ukur yang digunakan dalam penelitian ini reliabel karena Cronbach's Alpha > 0,60.

Uji normalitas menggunakan uji statistik non-parametrik Kolmogorov-Smirnov merupakan uji normalitas menggunakan fungsi distribusi kumulatif, hasil uji normalitas dengan nilai residual terstandarisasi berdistribusi normal jika nilai Sig. > alpha. Hasil pengujian normalitas sebesar $0,944>0,05$, hal ini berarti nilai residual terstandarisasi dinyatakan menyebar secara normal.

Tabel 1

\section{One-Sample Kolmogorov-Smirnov Test}

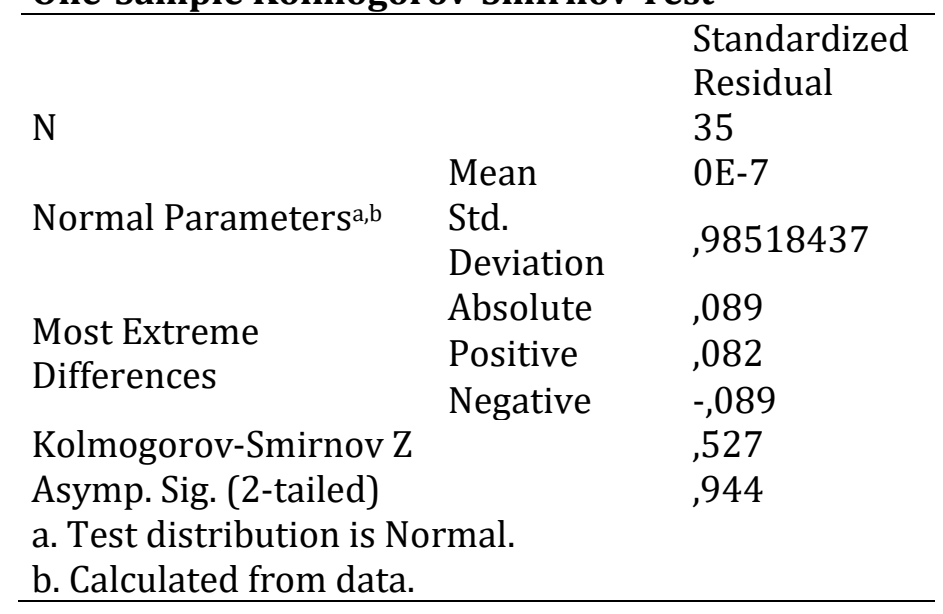

Uji heterokedastisitas dengan metode Glejser dilakukan dengan meregresikan variabel bebas terhadap nilai mutlak residualnya, jika terdapat pengaruh variabel bebas yang signifikan terhadap nilai mutlak residualnya maka dalam model terdapat masalah heterokedastisitas. Gejala heterokedastisitas ditunjukkan oleh koefisien regresi dari variabel bebas terhadap nilai absolut residualnya, jika nilai probabiltas lebih besar dari nilai alpha (Sig. $>\alpha$ ), maka dapat dipastikan model tidak mengandung gejala heteroskedastis atau dikatakan tidak terjadi heteroskedastisitas apabila $\mathrm{t}$ hitung $<\mathrm{t}$ tabel. Hasil uji heterokedastisitas partispasi anggaran terhadap absolut residual sebesar 0,109 >0,05, sehingga tidak terjadi heterokedastisitas.

Tabel.2

\section{Coefficients}

\begin{tabular}{|c|c|c|c|c|c|c|}
\hline \multirow{2}{*}{\multicolumn{2}{|c|}{ Model }} & \multicolumn{2}{|c|}{$\begin{array}{l}\text { Unstandardized } \\
\text { Coefficients }\end{array}$} & \multirow{2}{*}{$\begin{array}{c}\begin{array}{c}\text { Standardized } \\
\text { Coefficients }\end{array} \\
\text { Beta }\end{array}$} & \multirow[t]{2}{*}{$\mathrm{t}$} & \multirow[t]{2}{*}{ Sig. } \\
\hline & & $\mathrm{B}$ & Std. Error & & & \\
\hline & (Constant) & 9,609 & 4,298 & & 2,236 & ,032 \\
\hline & PA &,- 270 & ,164 & -275 & $-1,646$ & 109 \\
\hline \multicolumn{4}{|c|}{ a. Dependent Variable: ABRESID } & & & \\
\hline
\end{tabular}


Hasil Analisis Regresi Persamaan regresi yang diperoleh dari hasil pengujian hipotesis adalah sebagai berikut : $\mathrm{Y}=-4,746+1,622 \mathrm{X}$, dimana konstanta sebesar $-4,746$ artinya jika partisipasi anggaran sebesar 0(nol), maka kenierja manajerial sebesar 4,746. Dapat dikatakan bahwa apabila partisipasi anggaran tidak mengalami kenaikan/penurunan, maka kinerja manajerial tidak mengalami perubahan, tetapi apabila partisipasi anggaran mengalami kenaikan/penurunan maka kinerja manajerial akan mengalami perubahan. Koefisien regresi b atau patisipasi anggaran sebesar 1,622 artinya jika partisipasi anggaran mengalami kenaikan satu satuan, maka kinerja manajerial akan mengalami peningkatan 1,622 dengan signifikansi 0,000 lebih kecil dari $\alpha$ 0,05 dengan arah koefisien positif yang berarti terdapat pengaruh positif dan signifikan partisipasi anggaran terhadap kinerja manajerial.

Tabel.3

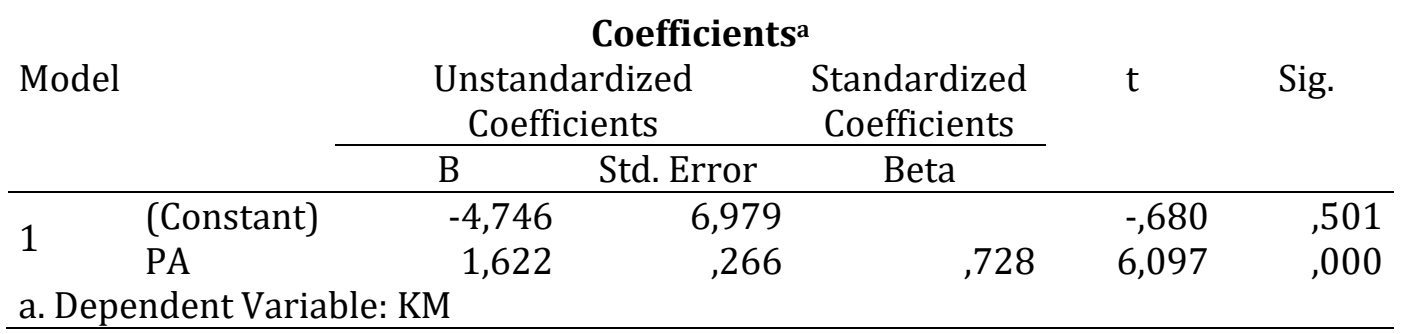

Koefisien diterminasi menunjukan $\mathrm{R}$ sebesar 0,728 menunjukkan korelasi antara partisipasi anggaran terhadap kinerja manajerial sebesar 0,728. Sedangkan R Square $\left(\mathrm{R}^{2}\right)$ adalah 0,530 atau 53\%, artinya bahwa variasi kinerja manajerial dapat dijelaskan oleh partisipasi anggaran sebesar 53\%, atau partisipasi anggaran mempengaruhi kinerja manajerial sebesar 53\%, sedangkan sisanya 47\% (100\%-53\%) dijelaskan atau ditentukan oleh variabel lain yang tidak diteliti dalam penelitian ini. Karena nilai $\mathrm{R}^{2}$ berkisar $0(\mathrm{nol})$ sampai 1 (satu) yang artinya apabila nilai $\mathrm{R}^{2}$ mendekati $0(\mathrm{nol})$, maka kemampuan variabel independen dalam menjelaskan variabel dependen sangat terbatas. Jika nila $\mathrm{R}^{2}$ mendekati 1 (satu), maka variabel independen dapat memberikan semua informasi yang dibutuhkan untuk memprediksi variabel dependen. Tabel.4

\begin{tabular}{|c|c|c|c|c|}
\hline \multicolumn{5}{|c|}{ Model Summaryb } \\
\hline Model & $\mathrm{R}$ & R Square & $\begin{array}{l}\text { Adjusted R } \\
\text { Square }\end{array}$ & $\begin{array}{l}\text { Std. Error of } \\
\text { the Estimate }\end{array}$ \\
\hline $\begin{array}{l}1 \\
\text { a. Pred } \\
\text { b. Dep }\end{array}$ & $\begin{array}{l}, 728^{a} \\
\text { s: (Cor } \\
\text { t Vari }\end{array}$ & $\begin{aligned} & 530 \\
& \text { zant), } \mathrm{PA} \\
& \text { le: } \mathrm{KM}\end{aligned}$ & ,515 & 3,431 \\
\hline
\end{tabular}




\section{PEMBAHASAN}

Hasil uji hipotesis 1 menunjukan bahwa partisipasi anggaran berpengaruh positif terhadap kinerja manajerial. Hasil penelitian ini menunjukkan bahwa Direksi dalam penyusunan Rencana Bisnis Bank harus berpartisipasi dengan baik karena semakin tinggi partisipasi dalam penyusunan Rencana Bisnis Bank akan meningkatkan kinerja manajerial, dengan teori penetapan tujuan bahwa dengan memahami anggara yang disusun maka akan meningkatkan motivasi untuk mencapai anggaran tersebut.

\section{PENUTUP}

\section{KESIMPULAN}

Berdasarkan hasil penelitian dan pembahasan dapat disimpulkan sebagai berikut: Partisipasi anggaran berpengaruh positif terhadap kinerja manajerial pada Bank Perkreditan Rakyat di wilayah Otoritas Jasa Keuangan Purwokerto. Hal ini menunjukan semakin tinggi tingkat partisipasi anggaran direksi dalam penyusunan Rencana Bisnis Bank maka kinerja manajerial yang dihasilkan akan meningkat, dimana Direksi sudah memahami Rencana Bisnis Bank tersebut karena dirkesi yang menyusunnya, sehingga akan memotivasi untuk mencapai target dalam Rencana Bisnis Bank.

\section{Saran}

Bagi para direksi yang dilibatkan dalam proses penyusunan anggaran, hendaknya memahami partisipasi dalam penyusunan anggaran merupakan sebuah kesempatan untuk menyusun anggaran yang terbaik dengan tujuan meningkatkan kinerjanya, bukan menjadi kesempatan untuk membuat anggaran yang lebih rendah dari kinerja yang sebenarnya mampu dicapai. Penelitian selanjutnya disarankan menambah variabel yang dapat mempengaruhi partisipasi anggaran terhadap kinerja manajerial, misalnya: inovasi, motivasi, kreatifitas dan sebagainya. Selain itu dapat juga memperluas obyek penelitian misalnya lingkup penelitian se Jawa Tengah.

\section{DAFTAR PUSTAKA}

Anthony dan Govindarajan, 2002, Sistem Pengendalian Manajemen, Salemba Empat, Jakarta. Argyris, C. 1952. The Impact of People on Budgets. New York, NY: Controllership Foundation Bronell, P., \& McInnes, M. (1986). Budgetary participation, motivation, and managerial performance. The Accounting Review, 61(4).

Cherrington, D. J. and J. O. Cherrington (1973). Appropriate Reinforcement Contingencies in the Budgeting Process. Journal of Accounting Research 11: 225-253. 
Chong, V. K., Eggleton, I. R. C., \& Leong, M. K. C. (2006). The multiple roles of participative budgeting on job performance. Advances in Accounting. http://dx.doi.org/10.1016/S0882-6110(06)22004-2

Chou, T.-K., \& Buchdadi, A. D. (2016). Bank Performance and Its Underlying Factors: A Study of Rural Banks in Indonesia. Accounting and Finance Research, 5(3), 55-63. http://doi.org/10.5430/afr.v5n3p55

Deliana, D. (2018). Managerial Performance in Indonesia Local Government : Impact of budget participation and budget goal commitment. Research Journal of Finance and Accounting. 6 No. 4.

Fakile, A. S., Ojeka, S.A, dan Oyewo, B. (2016). Determinants of subordinates' participation in budget planning: a study from Nigeria. Journal of Accounting, Finance and Auditing Studies, $2,43-59$

Fibrianti, D. and I. B. Riharjo (2013). Pengaruh Partisipasi Anggaran, Desentralisasi, Komitmen Organisasi, Dan Ketidakpastian Lingkungan Terhadap Kinerja Manajerial Pada Pemerintahan Kota Surabaya. Jurnal Ilmu dan Riset Akuntansi 1(1): 108-121.

Gray, R., Owen, D. and Maunders, K. (1987). Corporate Social Reporting: Emerging Trends In Accountability And The Social Contract. Accounting, Auditing \& Accountability Journal, Vol. 1 No. 1, pp. 6-20.

Handoko, 1997, Constructing Knowledge and Technology Transfer Model for SMEs Technology Development in Emerging Economies .ISSN 2597-7792 Vol 1 no 2

Hansen, D. R. and M. M. Mowen (2009). Managerial Accounting: Akuntansi Manajerial. Jakarta: Salemba Empat.

Hoque, Z. (2005). Linking environmental uncertainty to non-financial performance measures and performance: a research note. The British Accounting Review 37(4): 471-481.

Kamilah, F., Taufeni, T. dan Edfan, D. (2013). Pengaruh Partisipasi Anggaran Terhadap Kinerja Manajerial dengan Komitmen Organiasi dan gaya Kepemimpinan sebagai variabel Moderating ( Studi Empiris pada Rumah Sakit di Pekanbaru). Jurnal Sorot, 8, 105-119.

Kenis, I. 1979. Effects of budgetary goal characteristics on managerial attitudes and performance. The Accounting Review: 707-721

Kren, Leslie, 1992, Budgetary Participation and Managerial Performance: The Impact of Information and Environment Volatility, The Accounting Review, Juli, hal 511-526.

Lako, A. 2004. Kepemimpinan dan Kinerja Organisasi Isu Teori dan Solusi. Yogyakarta : Amara Books.

Locke, E. A. and G. P. Latham (1990). A theory of goal setting \& task performance, Prentice-Hall, Inc.

Lowin, A. and J. R. Craig (1968). The influence of level of performance on managerial style: An experimental object-lesson in the ambiguity of correlational data. Organizational behavior and human performance 3(4): 440-458.

Magner, N., R. B. Welker, and T. L. Campbell. 1996. Testing a model of cognitive budgetary participation processes in a latent variable structural equations framework. Accounting and Business Research: 41- 50.

Mahmudi, et al. (2010). Manajemen keuangan daerah. Jakarta, Erlangga.

Mahoney, T. A, Jerdee. J H, dan Carroll, S.J. (1963). The Job(s) of Management. Industrial Relations. Vol 4.97-110.

Mahsun, M. (2006). Pengukuran kinerja sektor publik. BPFE. Yogyakarta: 
Mangkunegara, A. P. and A. Prabu (2005). Evaluasi kinerja sumber daya manusia. Bandung: Refika Aditama.

Mardiasmo, D. and A. MBA (2009). Akuntansi Sektor Publik. Yogyakarta: ANDI.

Milani, K. (1975). The relationship of participation in budget-setting to industrial supervisor performance and attitudes: a field study. The Accounting Review 50(2): 274-284.

Murwaningsari, E. (2008). The role of organizational commitment and procedural justice in moderating the relationship between budgetary participation and managerial performance. Gadjah Mada International Journal of Business 10(2): 185-210.

Ompusungu, Krisler B. dan Icuk R. Bawono. 2007. "Pengaruh Partisipasi Anggaran Job Relevant Information (JRI) Terhadap Informasi Asimetris". Journal Akuntansi dan Keuangan Sektor Publik, Vol.08 No.01. Halaman 1371-1388

Otoritas Jasa Keuangan (2014). Peraturan Otoritas Jasa Keuangan Nomor 20/POJK. 03/2014 Tentang Bank Perkreditan Rakyat.

Otoritas Jasa Keuangan (2016). Peraturan Otoritas Jasa Keuangan Nomor 37/POJK. 03/2016 Tentang Rencana Bisnis Bank

Rachman, A. A. (2014). The Effect of Organization Commitment and Procedural Fairness on Participative Budgeting and Its Implication to Performance Moderating by Management Accounting Information (A Survey on Province Local Government Unit Agencies of West Java). Review of Integrative Business and Economics Research 3(1): 201.

Ramallo, S. (2016). The effect of trust, budget participation and empowerment on organizational performance. Business Administration Master's Thesis. Karlstad Business Scholl. Karlstad Universitet. Karlstad Sweden.

Safitri, Niken. 2006. Pengaruh Partisipasi dalam Penyusunan Anggaran Terhadap Kepuasan Kerja dan Kinerja Karyawan : Job Relevant Information (Jri) Sebagai Varibel Antara (Studi Pada PT. Merapi Utama Pharma Cabang Yogyakarta).

Septianto, Hendi dan Widiharih Tatik 2010). "Analisis Efisiensi Bank Perkreditan Rakyat Di kota Semarang Dengan Pendekatan Data Envolepment Analysis". Media Statistika, Vol. 3, No. 1 , pp 41-48

Siegel G, and Marconi, H.R. 1989. Behavioral Accounting. South Western Publishing Co

Simamora, H. (2012). Akuntansi Manajemen. III, Star Gate Publisher.

Undang-Undang, R.I (1998). No. 10 Tahun 1998. Tentang perbankan.

Wahyuningsih, S. dan Pramuka, B. A. (2012). Determinan Partisipasi Penganggaran dan Pengaruhnya Terhadap Kinerja Manajerial Aparat Pemerintah Daerah Kabupaten Banyumas. Jurnal Akuntansi dan Auditing 9(1): 1-15.

Welsh, Hilton, Gordon, diterjemahkan oleh Purwatiningsin dan Maudy Warouw, 2000,Anggaran; perencanaan dan pengendalian biaya, penerbit Salemba Empat, Jakarta.

Wibowo, S.(2010). Manajemen Kinerja . Edisi ketiga, Jakarta. PT Raja Grafindo Persada.

Wiratno, A., Ningsih, W. dan Putri, N.K. (2016). Partisipasi Anggaran Terhadap Kinerja Manajerial Dengan Komitmen Organisasi, Motivasi Dan Struktur Desentralisasi Sebagai Variabel Pemoderasi. Jurnal Akuntansi 20(1): 150-166.

Yuen. (2007). Antecedents of budgetary participation' enhancing employee's job performance.Managerial Auditing Journal, 22(5), 512- 526. https://doi.org/10.1108/02686900710750793

Yuen, D. (2007). Antecedents of budgetary participation: enhancing employees' job performance. Managerial Auditing Journal 22(5): 533-548. 